Prepared for the U.S. Department of Energy under Contract DE-AC05-76RL01830

\title{
Precipitate Formation Potential of Resin Regeneration Effluent in the 100-HR-3 Operable Unit
}

KJ Cantrell

October 2009

Pacific Northwest

NATIONAL LABORATORY

Proudly Operated by Battelle Since 1965 


\section{Precipitate Formation Potential of Resin Regeneration Effluent in the 100-HR-3 Operable Unit}

KJ Cantrell

October 2009

Prepared for the U.S. Department of Energy under Contract DE-AC05-76RL01830

Pacific Northwest National Laboratory

Richland, Washington 99352 


\section{Summary}

Calculations performed as part of this study indicate that injection of treated groundwater containing treated regenerant solution has a high potential for precipitate formation that could lead to plugging of formation porosity surrounding the injection well. Precipitate formation could lead to substantial loss in porosity on an annual basis at high injection rates, but is minimal at low injection rates. In the worst case scenario, substantial plugging could occur within a year of the initiation of injection. For example, assuming an injection rate of 600 gallons/minute, 24 hours/day and 365 days/year, an annual porosity loss of $7.3 \%$ is predicted for an initial solution $\mathrm{pH}$ of 7.0. At $\mathrm{pH} 8.0$, the annual porosity loss would increase to $16 \%$ per year. For cases in which solution injection is assumed to occur at a rate of 600 gallons/minute, 15 hours/day and 1 day/week, the annual porosity loss drops considerably. For these assumptions, the annual porosity loss is $0.65 \%$ for an initial solution $\mathrm{pH}$ of 7.0 and $1.4 \%$ for an initial solution $\mathrm{pH}$ of 8.0 .

Some uncertainty is associated with respect to these analyses. The uncertainty results from the fact that equilibrium with the most stable mineral assemblage cannot always be assumed and that slow precipitation rates could occur and reliable estimates of precipitation kinetics under Hanford aquifer conditions are not available. It is recommended that the potential of calcium phosphate precipitation be investigated further using a combination of laboratory and field investigations to reduce this uncertainty. 


\section{Contents}

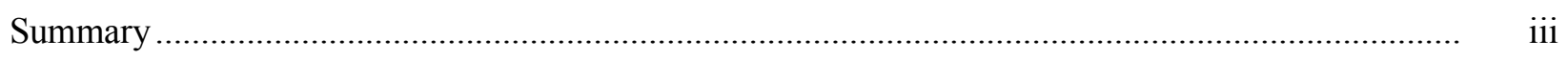

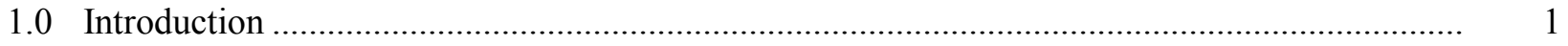

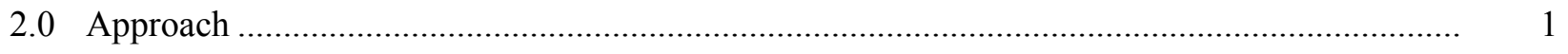

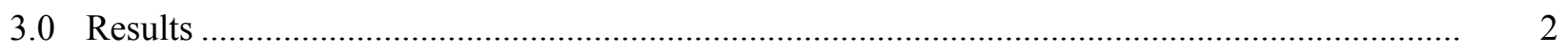

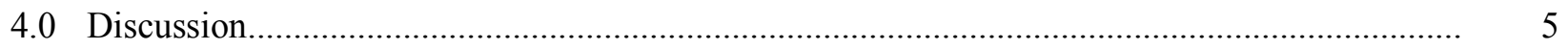

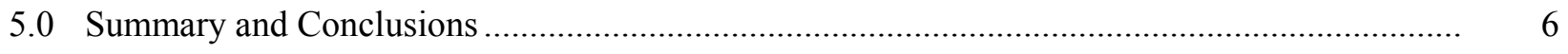

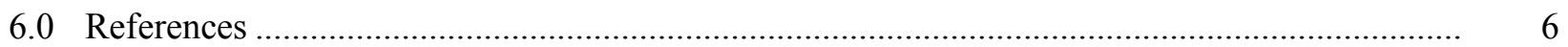

\section{Tables}

1 Estimated Parameters for Treated Groundwater Containing Treated Regenerant from the 100-DX Facility

2 Calculated Saturation Index (SI) Values for Treated Groundwater Containing Treated

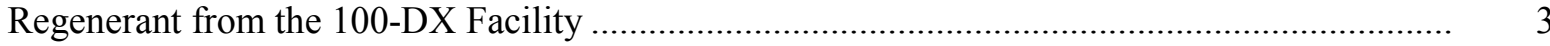

3 Mass of Minerals Precipitated from Treated Regenerant After Equilibrium............................. 3

4 Volume of Minerals Precipitated from Treated Regenerant After Equilibrium .......................... 3

5 Volume of Minerals Precipitated from Treated Regenerant After Equilibrium While

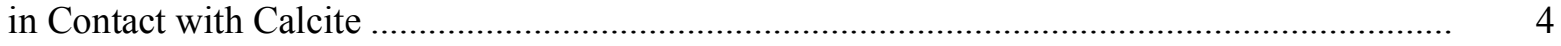

6 Percentage of Porosity Calculated to be Filled by Precipitates After One Year for Various Scenarios Assuming Injection at 24 Hours/Day......................................................... 4

7 Percentage of Porosity Calculated to be Filled by Precipitates After One Year for Various Scenarios Assuming Injection at 15 Hours/Week 


\subsection{Introduction}

Ion-exchange resins are used to treat groundwater contaminated with hexavalent chromium during pump-and-treat operations. Multiple resin regeneration approaches are being evaluated for treatment options. One approach is in-vessel regeneration of the ion-exchange resins. This approach produces approximately 1,000 gallons of effluent high in total dissolved solids including calcium, phosphate, and sulfate. Several options are being considered for disposal of the effluent, including transfer to the Treated Effluent Disposal Facility for processing, onsite evaporation and disposal of solids, co-injection of either filtered or unfiltered effluent with regular injection water after it passes through treatment at the 100-DX facility, 100-HR-3 Operable Unit, or other treatment system.

In the reinjection option, effluent is pumped into the aquifer via injection wells subsequent to $\mathrm{pH}$ neutralization. A concern with this approach is the potential degradation of injection performance over time as a result of scale build-up in the well screen, filter pack, and surrounding aquifer.

The purpose of this report is to apply geochemical modeling techniques to evaluate the potential for precipitate formation in the ion-exchange regeneration effluent solutions as they are re-injected into the subsurface aquifer and to determine its potential impact on aquifer porosity.

\subsection{Approach}

The React module of The Geochemist's Workbench ${ }^{\circledR}$ software package was used to model the chemical equilibrium of the system and to identify and determine the quantities of minerals that could potentially precipitate. Two approaches were taken to model the system. In the first approach, an initial solution composition was assumed and was allowed to come to equilibrium by allowing minerals to precipitate until equilibrium was established. Once equilibrium was established, the quantities of minerals that precipitated to reach equilibrium were quantified.

In the second approach, reaction path modeling was used. In this approach, an initial solution of assumed composition is reacted with the mineral calcite $\left(\mathrm{CaCO}_{3}\right)$ which is commonly present in Hanford sediments. In this case, if any new calcium containing precipitates form, the solution will likely become undersaturated with respect to calcite and calcite will dissolve until the system reaches equilibrium with respect to the new precipitates.

Table 1 shows the estimated parameters for treated groundwater containing treated regenerant from the 100-DX facility that were used in the geochemical modeling. Runs were made at four different $\mathrm{pH}$ values (7.0, 7.8, 8.0 and 8.5), with all other parameters being held constant. 
Table 1. Estimated Parameters for Treated Groundwater Containing Treated Regenerant from the 100-DX Facility (personal communication John Smoot)

\begin{tabular}{cc}
\hline Constituent & Concentration $(\mathrm{mg} / \mathrm{L})$ \\
\hline $\mathrm{Ca}$ & 63.5 \\
$\mathrm{Mg}$ & 14.8 \\
$\mathrm{Na}$ & 88 \\
$\mathrm{~K}$ & 4.59 \\
$\mathrm{HCO}_{3}$ & 106 \\
$\mathrm{SO}_{4}$ & 193 \\
$\mathrm{NO}_{3}$ & 30.6 \\
$\mathrm{Cl}$ & 64 \\
$\mathrm{~F}$ & 0.0654 \\
$\mathrm{HPO}_{4}$ & 2 \\
$\mathrm{pH} \mathrm{range}$ & 7.0 to 8.5 \\
$\mathrm{O}_{2}$ & 8 \\
Temperature & $20^{\circ} \mathrm{C}$ \\
\hline
\end{tabular}

\subsection{Results}

Saturation indices (SIs) for relevant minerals calculated for the initial treated regenerant solution at the four $\mathrm{pH}$ values are shown in Table 2. The saturation index is defined as $\mathrm{SI}=\log \left(\mathrm{Q} / \mathrm{K}_{\mathrm{sp}}\right)$, where $\mathrm{Q}$ is the ion activity product and $\mathrm{K}_{\mathrm{sp}}$ is the mineral solubility product at equilibrium at the specified temperature. Minerals with SI values near zero are generally considered to be near equilibrium with the solution composition; more positive values are considered oversaturated; and more negative values are considered undersaturated. Results of the saturation index calculations indicate that the injection solution (treated groundwater containing treated regenerant) is highly oversaturated with respect to fluorapatite $\left[\mathrm{Ca}_{5}\left(\mathrm{PO}_{4}\right)_{3} \mathrm{~F}\right]$ at all $\mathrm{pH}$ values considered. Hydroxylapatite $\left[\mathrm{Ca}_{5}(\mathrm{OH})\left(\mathrm{PO}_{4}\right)_{3}\right]$ is highly oversaturated at $\mathrm{pH}$ values of 7.8 and higher. Whitlockite $\left[\mathrm{Ca}_{3}(\mathrm{PO})_{2}\right]$ is somewhat oversaturated at $\mathrm{pH} 7.8$ and becomes significantly oversaturated at $\mathrm{pH}$ 8.5. Calcite $\left(\mathrm{CaCO}_{3}\right)$ is undersaturated at $\mathrm{pH} 7.0$, essentially at equilibrium at $\mathrm{pH} 7.8$ and somewhat oversaturated at $\mathrm{pH}$ 8.5. The SI index for monohydrocalcite $\left(\mathrm{CaCO}_{3} \cdot \mathrm{H}_{2} \mathrm{O}\right)$ is included in Table 2 because it is a key precursor to $\mathrm{CaCO}_{3}$ precipitation (Elfil and Hannaci 2006). Monohydrocalcite is undersaturated throughout the $\mathrm{pH}$ range considered. Gypsum in also significantly undersaturated throughout the $\mathrm{pH}$ range considered.

Subsequent to the initial determination of saturation indices, the solutions were then allowed to equilibrate to determine the mass of minerals that would precipitate from a single liter of solution. Results of these modeling calculations are shown in Table 3. The results indicate that fluorapatite could precipitate at a consistent value for all $\mathrm{pH}$ values considered. Hydroxylapatite does not precipitate at $\mathrm{pH}$ 7.0, but significant precipitation can occur at $\mathrm{pH} 7.8$ to 8.5 . Calcite precipitation does not occur at $\mathrm{pH}$ values of 7.0 and 7.8. Minor amounts of calcite are predicted to precipitate at $\mathrm{pH} 8.0$ and relatively large amounts of precipitation are expected at $\mathrm{pH}$ 8.5. Based on the masses of these precipitates and the 
densities of the corresponding phases, the volumes of the precipitates that could form were calculated and are presented in Table 4.

Table 2. Calculated Saturation Index (SI) Values for Treated Groundwater Containing Treated Regenerant from the 100-DX Facility

\begin{tabular}{lcccc}
\hline \multicolumn{1}{c}{ Mineral } & $\mathrm{SI}(\mathrm{pH} 7.0)$ & $\mathrm{SI}(\mathrm{pH} 7.8)$ & $\mathrm{SI}(\mathrm{pH} 8.0)$ & $\mathrm{SI}(\mathrm{pH} 8.5)$ \\
\hline fluorapatite $\left[\mathrm{Ca}_{5}\left(\mathrm{PO}_{4}\right)_{3} \mathrm{~F}\right]$ & 9.44 & 12.6 & 13.3 & 14.9 \\
hydroxylapatite $\left[\mathrm{Ca}_{5}(\mathrm{OH})\left(\mathrm{PO}_{4}\right)_{3}\right]$ & -0.27 & 3.72 & 4.59 & 6.66 \\
whitlockite $\left[\mathrm{Ca}_{3}\left(\mathrm{PO}_{4}\right)_{2}\right]$ & -1.63 & 0.50 & 0.95 & 2.00 \\
calcite $\left(\mathrm{CaCO}_{3}\right)$ & -0.86 & 0.01 & 0.21 & 0.70 \\
monohydrocalcite $\left(\mathrm{CaCO}_{3} \cdot \mathrm{H}_{2} \mathrm{O}\right)$ & -1.68 & -0.81 & -0.61 & -0.12 \\
gypsum $\left(\mathrm{CaSO}_{4} \cdot \mathrm{H}_{2} \mathrm{O}\right)$ & -1.48 & -1.48 & -1.49 & -1.49 \\
\hline
\end{tabular}

Table 3. Mass of Minerals Precipitated from Treated Regenerant After Equilibrium

\begin{tabular}{lcccc}
\hline \multicolumn{1}{c}{ Mineral } & $\begin{array}{c}\mathrm{pH} 7.0 \\
(\mathrm{mg} / \mathrm{L})\end{array}$ & $\begin{array}{c}\mathrm{pH} 7.8 \\
(\mathrm{mg} / \mathrm{L})\end{array}$ & $\begin{array}{c}\mathrm{pH} 8.0 \\
(\mathrm{mg} / \mathrm{L})\end{array}$ & $\begin{array}{c}\mathrm{pH} 8.5 \\
(\mathrm{mg} / \mathrm{L})\end{array}$ \\
\hline fluorapatite & 1.71 & 1.71 & 1.71 & 1.71 \\
hydroxylapatite & 0.00 & 1.40 & 1.53 & 1.54 \\
calcite & 0.00 & 0.00 & 0.41 & 7.12 \\
\hline
\end{tabular}

Table 4. Volume of Minerals Precipitated from Treated Regenerant After Equilibrium

\begin{tabular}{|c|c|c|c|c|}
\hline Mineral & $\begin{array}{l}\mathrm{pH} 7.0 \\
\left(\mathrm{~cm}^{3} / \mathrm{L}\right)\end{array}$ & $\begin{array}{l}\mathrm{pH} 7.8 \\
\left(\mathrm{~cm}^{3} / \mathrm{L}\right)\end{array}$ & $\begin{array}{l}\mathrm{pH} 8.0 \\
\left(\mathrm{~cm}^{3} / \mathrm{L}\right)\end{array}$ & $\begin{array}{l}\mathrm{pH} 8.5 \\
\left(\mathrm{~cm}^{3} / \mathrm{L}\right)\end{array}$ \\
\hline fluorapatite & $5.43 \times 10^{-4}$ & $5.43 \times 10^{-4}$ & $5.43 \times 10^{-4}$ & $5.43 \times 10^{-4}$ \\
\hline hydroxylapatite & $0.00 \times 10^{-4}$ & $4.44 \times 10^{-4}$ & $4.85 \times 10^{-4}$ & $4.88 \times 10^{-4}$ \\
\hline calcite & $0.00 \times 10^{-4}$ & $0.00 \times 10^{-4}$ & $1.50 \times 10^{-4}$ & $2.63 \times 10^{-3}$ \\
\hline Total & $5.43 \times 10^{-4}$ & $9.88 \times 10^{-4}$ & $1.18 \times 10^{-3}$ & $3.66 \times 10^{-3}$ \\
\hline
\end{tabular}

Results from the reaction path modeling approach are shown in Table 5 in terms of volume of precipitate formed. In this approach, the initial solution is assumed to be in contact with calcite and is then allowed to come to equilibrium with the new precipitates. The volumes of fluorapatite and hydroxyapatite are similar and remain relatively constant throughout the $\mathrm{pH}$ range considered. At $\mathrm{pH}$ 7.0, a significant amount of calcite dissolution is predicted to occur, resulting in a significant negative net volume change. At pH 7.8, the volume of calcite dissolved is similar to the total of the volumes of fluorapatite and hydroxyapatite precipitated, resulting in a small net increase in precipitate volume. At $\mathrm{pH}$ values of 8.0 and 8.5, the results for reaction path modeling approach are identical to those of the simple equilibration approach. This is because at $\mathrm{pH} 8.5$ the solution is initially oversaturated with respect to calcite, so contact with calcite has no impact on the final equilibrated solution. 
Table 5. Volume of Minerals Precipitated from Treated Regenerant After Equilibrium While in Contact with Calcite

\begin{tabular}{|c|c|c|c|c|}
\hline Mineral & $\begin{array}{c}\mathrm{pH} 7.0 \\
\text { Volume }\left(\mathrm{cm}^{3} / \mathrm{L}\right)\end{array}$ & $\begin{array}{c}\mathrm{pH} 7.8 \\
\text { Volume }\left(\mathrm{cm}^{3} / \mathrm{L}\right)\end{array}$ & $\begin{array}{c}\mathrm{pH} 8.0 \\
\text { Volume }\left(\mathrm{cm}^{3} / \mathrm{L}\right)\end{array}$ & $\begin{array}{c}\mathrm{pH} 8.5 \\
\text { Volume }\left(\mathrm{cm}^{3} / \mathrm{L}\right)\end{array}$ \\
\hline fluorapatite & $5.43 \times 10^{-4}$ & $5.43 \times 10^{-4}$ & $5.43 \times 10^{-4}$ & $5.43 \times 10^{-4}$ \\
\hline hydroxylapatite & $5.13 \times 10^{-4}$ & $4.83 \times 10^{-4}$ & $4.85 \times 10^{-4}$ & $4.88 \times 10^{-4}$ \\
\hline calcite & $-9.70 \times 10^{-3}$ & $-8.49 \times 10^{-4}$ & $1.50 \times 10^{-4}$ & $2.63 \times 10^{-3}$ \\
\hline Total & $-8.64 \times 10^{-3}$ & $1.39 \times 10^{-4}$ & $1.18 \times 10^{-3}$ & $3.66 \times 10^{-3}$ \\
\hline
\end{tabular}

The impact of precipitate formation on porosity was calculated based on the volume of precipitates formed per liter of water and assumptions regarding injection rate and aquifer porosity (personal communication John Smoot). Two sets of assumptions were used for these calculations. For the first case, the following assumptions were used: 1) the treated regenerant solution is injected at a rate of 600 gallons/minute, 24 hours/day and 365 days/year; 2) the screened interval in which solution is injected into the aquifer is 20 feet thick; 3) the precipitates form within 5 feet of the injection well; and 4) the effective aquifer porosity is $20 \%$.

Results of the impact of precipitate formation on porosity for the eight geochemical scenarios considered and the first set of injection assumptions are shown in Table 6. The calculated results for equilibration of the initial solution (without contact with calcite) indicate that significant porosity loss is likely at all $\mathrm{pH}$ values considered and that the loss increases significantly as the $\mathrm{pH}$ increases from 7.0 to 8.5. At $\mathrm{pH} 7.0$, the porosity loss is $7.3 \%$ per year, while at $\mathrm{pH} 8.5$ the loss is $49 \%$ per year.

Table 6. Percentage of Porosity Calculated to be Filled by Precipitates After One Year for Various Scenarios Assuming Injection at 24 Hours/Day

\begin{tabular}{lc}
\hline \multicolumn{1}{c}{ Scenario } & $\begin{array}{c}\text { Percentage of Porosity } \\
\text { Lost After One Year }\end{array}$ \\
\hline Equilibration of Initial Solution (pH 7.0) & 7.3 \\
Equilibration of Initial Solution (pH 7.8) & 13 \\
Equilibration of Initial Solution (pH 8.0) & 16 \\
Equilibration of Initial Solution ( $\mathrm{pH} 8.5)$ & 49 \\
Equilibration of Initial Solution (pH 7.0) in Contact with Calcite & -116 \\
Equilibration of Initial Solution (pH 7.8) in Contact with Calcite & 1.9 \\
Equilibration of Initial Solution (pH 8.0) in Contact with Calcite & 16 \\
Equilibration of Initial Solution (pH 8.5) in Contact with Calcite & 49 \\
\hline
\end{tabular}

The results for the reaction path modeling case in which it is assumed that the initial solution contacts calcite that could be available in the aquifer matrix indicate that a significant gain in porosity would occur for injection of the $\mathrm{pH} 7.0$ solution. This is because the porosity loss from the precipitation of fluorapatite and hydroxylapatite is small compared to the quantity of calcite that dissolves. This porosity gain will only be applicable as long as calcite is available in the aquifer material for dissolution. Once all the calcite has dissolved, the porosity loss rate would return to 7.3\% per year. At $\mathrm{pH} 7.8$, contact with calcite (calcite dissolution) results in a significant reduction in the rate of porosity loss (from 7.3 to $1.9 \%$ per 
year). Again, for this case, once all the calcite in the aquifer matrix has dissolved the porosity loss rate will return the higher value of $13 \%$ per year. At $\mathrm{pH}$ values of 8.0 and 8.5 , contact with calcite has not impact on the porosity loss rate. This is because at these $\mathrm{pH}$ values the initial solutions are already oversaturated with respect to calcite.

Additional calculations were made for an alternative injection scenario. In this case, the following assumptions were used: 1) the treated regenerant solution is injected at a rate of 600 gallons/minute, 15 hours/day for 1 day/week; 2) the screened interval in which solution is injected into the aquifer is 20 feet thick; 3) the precipitates form within 5 feet of the injection well; and 4) the effective aquifer porosity is $20 \%$. The results for initial solutions at $\mathrm{pH} 7.0$ and 8.0 are shown in Table 7 . For these assumptions, the annual porosity losses are considerably lower at $0.65 \%$ for an initial $\mathrm{pH}$ of 7.0 and $1.4 \%$ for $\mathrm{pH} 8.0$.

Table 7. Percentage of Porosity Calculated to be Filled by Precipitates After One Year for Various Scenarios Assuming Injection at 15 Hours/Week

\begin{tabular}{cc}
\hline Scenario & $\begin{array}{c}\text { Percentage of Porosity } \\
\text { Lost After One Year }\end{array}$ \\
\hline Equilibration of Initial Solution $(\mathrm{pH} \mathrm{7.0)}$ & 0.65 \\
Equilibration of Initial Solution $(\mathrm{pH} \mathrm{8.0)}$ & 1.4 \\
\hline
\end{tabular}

\subsection{Discussion}

Although the calculations discussed in Section 3.0 are expected to be reliable with respect to the precipitates that may occur within the assumption of thermodynamic equilibrium, some uncertainty exists with respect the rate at which the precipitates will occur. The uncertainty results from the fact that equilibrium with an alteration mineral assemblage cannot always be assumed, especially in systems where low temperature leads to slow rates of chemical reaction, or if there exists a perturbation away from equilibrium, e.g., relatively fast hydrologic flow rates from one geochemical regime into another (Palandri and Kharaka 2004). As a result, precipitation rate data are necessary to determine how fast the precipitation would occur relative to expected injection flow rates.

Unfortunately, precipitation rate data do not exist for most minerals. This is due primarily because in mineral precipitation experiments, undesired metastable reaction products usually precipitate instead of the desired mineral, especially far from equilibrium at high degrees of supersaturation. An example of this behavior is the precipitation of amorphous silica from fluids that are grossly supersaturated with respect to quartz $\left(\mathrm{SiO}_{2}\right)$. In addition, quartz precipitation is prohibitively slow at ambient temperatures and low degrees of supersaturation. When precipitation rate data are available, the rates are typically dependent upon surface area of the minerals of interest, which can be difficult to evaluate and change as the precipitation process proceeds.

The precipitation kinetics of calcium phosphate is important in a wide range of applications including materials science, orthopedics and plastic surgery, and environmental science and engineering. As a result, precipitation kinetics of calcium phosphate has been the subject of many studies (e.g., Oliveira 
et al. 2007; Hafez et al. 2006; Liu et al. 2001; Rodriquez-Clemente et al. 1998; Gasser et al. 1994; Brown et al. 1991). Unfortunately, the conditions used to study calcium phosphate precipitation kinetics in these studies are not relevant to or cannot be readily extrapolated to Hanford aquifer conditions.

The conditions studied by Hafez et al. (2006) appear to be the most relevant to those of a Hanford aquifer. Hafez et al. (2006) determined that dicalcium phosphate dihydrate $\left(\mathrm{CaHPO}_{4} \cdot 2 \mathrm{H}_{2} \mathrm{O}\right)$, the least thermodynamically stable crystalline form of calcium phosphate, formed predominantly at $25^{\circ} \mathrm{C}$ and initial $\mathrm{pH}$ values lower than 7.0. In the presence of sand grain substrates, dicalcium phosphate dihydrate was stabilized to some extent even at relatively high $\mathrm{pH}$. Octacalcium phosphate $\left[\mathrm{Ca}_{8} \mathrm{H}_{2}\left(\mathrm{PO}_{4}\right) \cdot 5 \mathrm{H}_{2} \mathrm{O}\right]$ and hydroxylapatite $\left[\mathrm{Ca}_{5}(\mathrm{OH})\left(\mathrm{PO}_{4}\right)_{3}\right]$ were the predominant phases at $50^{\circ} \mathrm{C}$ and $70^{\circ} \mathrm{C}$ both in the presence and absence of sand in the $\mathrm{pH}$ range of 6 to 8 . Unfortunately, data are not available for lower temperature conditions more relevant to a Hanford aquifer (approximately $15^{\circ} \mathrm{C}$ ).

\subsection{Summary and Conclusions}

Calculations performed as part of this study indicate that injection of treated groundwater containing treated regenerant solution has a high potential for precipitate formation that could lead to plugging of formation porosity surrounding the injection well. Precipitate formation could lead to substantial loss in porosity on an annual basis at high injection rates, but is minimal at low injection rates. In the worst case scenario, substantial plugging could occur within a year of the initiation of injection. For example, assuming an injection rate of 600 gallons/minute, 24 hours/day and 365 days/year, an annual porosity loss of $7.3 \%$ is predicted for an initial solution $\mathrm{pH}$ of 7.0. At $\mathrm{pH} 8.0$, the annual porosity loss would increase to $16 \%$ per year. For cases in which solution injection is assumed to occur at a rate of 600 gallons/minute, 15 hours/day and 1 day/week, the annual porosity loss drops considerably. For these assumptions, the annual porosity loss is $0.65 \%$ for an initial solution $\mathrm{pH}$ of 7.0 and $1.4 \%$ for an initial solution $\mathrm{pH}$ of 8.0.

Some uncertainty is associated with respect to these analyses. The uncertainty results from the fact that equilibrium with the most stable mineral assemblage cannot always be assumed and that slow precipitation rates could occur and reliable estimates of precipitation kinetics under Hanford aquifer conditions are not available. It is recommended that the potential of calcium phosphate precipitation be investigated further using a combination of laboratory and field investigations to reduce this uncertainty.

\subsection{References}

Brown PW, N Hocker, and S Hoyle. 1991. "Variations in Solution Chemistry during the LowTemperature Formation of Hydroxyapatite." Journal of the American Ceramic Society 74(8):1848-1854.

Elfil H and A Hannaci. 2006. "Reconsidering Water Scaling Tendency Assessment." AIChE Journal 52(10):3583-3591. 
Gasser P, Y Haikel, JC Voegel, and Ph Gramain. 1994. "Surface Reactions of Hydroxyapatite in the Presence of Fluoride Ions. 2. Effects of Calcium and Phosphate in Saturated Solutions." Colloids and Surfaces A: Physiochemical and Engineering Aspects 88:157-168.

Hafez IT, CA Paraskeva, A Toliza, PG Klepetsanis, PG Koutsoukos, O Gustavsen, T Ostvold, and AC Payatakes. 2006. "Calcium Phosphate Overgrowth on Silicate Sand." Crystal Growth \& Design 6(3):675-683.

Liu C, Y Huang, W Shen, and J Cui. 2001. "Kinetics of Hydroxyapatite Precipitation at pH 10 to 11." Biomaterials 22:301-306.

Oliveira C, A Ferreira and F Rocha. 2007. "Dicalcium Phosphate Dihydrate Precipitation Characterization and Crystal Growth." Transactions of the Institution of Chemical Engineers 85(A12):1655-1661.

Palandri JL and YK Kharaka. 2004. A Compilation of Rate Parameters of Water-Mineral Interaction Kinetics for Application to Geochemical Modeling. U.S. Geological Survey, Open File Report 2004-1068, Menlo Park, California.

Rodriquez-Clemente R, A Lopez-Macipe, J Gomez-Morales, J Rorrent-Burgues and VM Castano. 1998. "Hydroxyapatite Precipitation: A Case of Nucleation-Aggregation-Agglomeration-Growth Mechanism." Journal of the European Ceramic Society 18:1351-1356. 


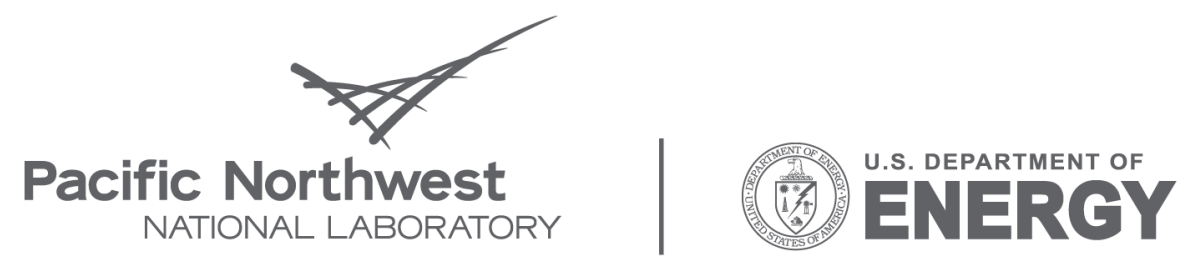

Proudly Operated by Battelle Since 1965

902 Battelle Boulevard

P.O. Box 999

Richland, WA 99352

1-888-375-PNNL (7665)

www.pnl.gov 